\title{
Analisis Usability Pada Aplikasi Mobile Pemeriksa Kesehatan Mata
}

\author{
Adhytia Ihza Mahendra ${ }^{1}$, Meredita Susanty ${ }^{2}$ \\ 1,2 Universitas Pertamina \\ Jl Teuku Nyak Arief, Simprug, Kebayoran Lama, Jakarta Selatan 12220, Indonesia \\ e-mail: 'adhytiaihzamahendra@gmail.com, ${ }^{2}$ meredita.susanty@universitaspertamina.ac.id
}

\begin{tabular}{llll}
\hline Informasi Artikel Diterima: 30-06-2021 Direvisi: 28-07-2021 Disetujui: 30-07-2021 \\
\hline
\end{tabular}

\begin{abstract}
Abstrak
Kesehatan mata harus terjaga dengan baik karena peran kedua mata sangat penting bagi kehidupan manusia. Namun tahun 2012 Indonesia memiliki angka gangguan penglihatan yang cukup tinggi sebesar $1,5 \%$ dari seluruh penduduk indonesia atau sekitar 3,6 juta jiwa. Pemerintah Indonesia telah menyiapkan sarana dan prasarana pelayanan kesehatan yang baik di puskesmas maupun rumah sakit. Sayangnya, kesadaran masyarakay untuk datang dan memeriksakan matanya di fasilitas kesehatan yang telah ditentukan masih rendah. Meningkatnya pengguna internet dan mobile phone mendorong perkembangan teknologi dan memunculkan inovasi - invasi baru. Salah satunya adalah Aplikasi Mataku, sebuah aplikasi berbasis Android yang membantu untuk melakukan pengecekan dini terhadap berbagai penyakit mata seperti penyakit katarak, pterigium, buta warna, dan miopi. Melalui aplikasi ini ini pengguna juga dapat berkonsultasi dengan dokter spesialis mata secara daring. Untuk menjamin aplikasi dapat dengan mudah digunakan oleh pengguna, perlu dilakukan pengujian usability dengan parameter learnability, efficiency, memorability, errors dan satisfaction. Pengujian ini menggunkan metode usability testing terhadap purwarupa aplikasi. Hasil pengujian ini menunjukkan adanya permasalahan pada salah satu fitur pada aplikasi. Perbaikan desain berdasarkan rekomendasi perbaikan yang diberikan menunjukkan perbaikan pada beberapa parameter namun menimbulkan masalah untuk parameter lain. Hasil penelitian ini diharapkan dapat meningkatkan kualitas aplikasi Mataku sekaligus menjadi contoh kasus bagi pihak lain yang berkecimpung di bidang desain user interface dan user experience.
\end{abstract}

Kata Kunci: user interface, user experience, usability

\begin{abstract}
Having perfectly healthy eyes_excellent vision and clear eyes, free of pain or other symptoms-are crucial to our health and well-being. However, about 1.5\% of Indonesian or around 3.6 million people have some vision problems in 2012. Although the Indonesian government provides health service facilities and infrastructure, the public's awareness of doing eye exams is still low. The Internet and mobile phone usage boost an innovation to address this low awareness. Mataku, an Android-based application that helps to perform early checks on various eye diseases such as cataracts, pterygium, colour blindness, and myopia, comes as an alternative to traditional health facilities. Using this application, users can also do online consultation with an ophthalmologist. In order to make user willing to use the application, it must enable the users to complete the task accurately and operate it in a pleasant mood. To measure those qualities, it necessary to performs usability testing. This research aims to measure usability using the usability testing method. The parameters that are measured are learnability, efficiency, memorability, errors, and satisfaction. The results indicate a problem with one of the features in the application. The revised version of the prototype shows improvement in some parameters but cause problems for other parameters. The results of this study are expected to improve the quality of the Mataku application and as a study case for other researcher or UI/UX designer in performing a design.
\end{abstract}

Keywords: user interface, user experience, usability 


\section{Pendahuluan}

Tahun 2012 sebesar 1,5\% dari seluruh penduduk Indonesia atau sekitar 3,6 juta jiwa mengalami gangguan penglihatan diantaranya katarak, kelainan kornea, glukoma, dan penyakit lainnya (Sahlan, 2013). Walaupun pemerintah sudah menyiapkan sarana dan prasarana pelayanan kesehatan dan Jaminan Kesehatan Nasional untuk masyarakat miskin termasuk untuk operasi katarak namun kesadaran masyarakat untuk memeriksakan Kesehatan mata secara teratur masih rendah(Kementerian Kesehatan Republik Indonesia, n.d.).

Meningkatnya pengguna internet dan mobile phone memungkinkan pemeriksaan kesehatan mata dilakukan secara daring baik dengan bantuan teknologi maupun melalui konsultasi daring dengan dokter spesialis mata. Inovasi ini diharapkan dapat meningkatkan kesadaran masyarakat untuk melakukan pemeriksaan mata secara rutin sehingg dapat menurunkan angka gangguan penglihatan di Indonesia. Mataku, sebuah aplikasi berbasis Android untuk pengecekan dini terhadap berbagai penyakit mata seperti katarak, pterigium, buta warna, dan miopi . Melalui aplikasi ini pengguna juga dapat berkonsultasi dengan dokter spesialis mata yang sudah terdaftar di aplikasi.

Agar calon pengguna tertarik menggunakan aplikasi Mataku dan pengguna menggunakan aplikasi ini secara rutin untuk melakukan pemeriksaan mata, maka aplikasi harus mudah digunakan oleh pengguna sehingga pengguna dapat melakukan suatu task hingga berhasil dengan suasa hati yang baik. Tidak ada perancang user interface yang tahu dengan baik bagaimana cara merancang user interface yang cukup baik tanpa adanya perancangan kembali yang didukung oleh pengamatan pengguna dan interaksi mereka dengan desain (Moran, 2019). Jika sebuah aplikasi sulit untuk digunakan, tidak mampu memberikan informasi dengan jelas, atau informasi sulit dibaca sehingga tidak dapat menjawab pertanyaan-pertanyaan penting dari pengguna, maka aplikasi tersebut akan ditinggalkan oleh pengguna(Nielsen, 2012a). Oleh karena itu, perlu dilakukan pengujian usabilitas terhadap aplikasi yang mengukur sejauh mana tingkat learnability, efficiency, memorability, errors dan satisfaction (Belson \& Ho, 2012; Nielsen, 2001) pada aplikasi Mataku. Penelitian ini bertujuan melakukan pengukuran tingkat usabilitas berdasarkan parameter learnability, efficiency, memorability, errors dan satisfaction terhadap lima fitur utama aplikasi Mataku menggunakan metode usability testing (Rubin \& Chisnell, 2018).
Melalui penelitian ini diharapkan dapat mengetahui permasalahan usabilitas pada aplikasi dan dilakukan upaya perbaikan desain untuk meningkatkan kualitas aplikasi.

\section{Metode Penelitian}

Penelitian untuk mengukur tingkat learnability, efficiency, memorability, errors dan satisfaction terhadap lima fitur utama aplikasi Mataku yaitu cek katarak, cek pterigium cek buta warna,cek miopia dan konsultasi dokter. Pengujian dilakukan terhadap high fidelity prototype menggunakan remote usability testing pada situasi controlled setting.

Parameter ini diukur menggunakan metriks yang dijelaskan pada Tabel 1 (Hartson \& Pyla, 2018; Jakob Nielsen, 2001; Luchita, 2019; Nielsen, 2001). Learnability menjadi acuan seberapa cepat pengguna dapat menyesuaikan diri dengan lingkungan sistem aplikasi yang sedang diuji secara objektif. Aspek ini mempertimbangkan seberapa mudahnya pengguna menyelesaikan task saat pertama kali mereka berinteraksi dengan interface aplikasi . Dalam pengukuran tingkat learnability, digunakan indikator Completion Metrics dan nilai errors sebagai acuan. Tingkat kesalahan yang dilakukan oleh pengguna dihitung kemudian dicari tahu berapa banyak pengulangan yang dibutuhkan sehingga tugas yang diberikan dapat memenuhi standard metrik yang telah ditentukan(Hartson \& Pyla, 2018).

Effisiensi diukur dengan satuan waktu yang dibutuhkan oleh pengguna untuk menyelesaikan task yang diberikan hingga sukses (duration metrics). Tingkat efficiency diukur dengan 2 cara yaitu Time-Based Efficiency dan Overall Relative Efficiency(Justin Mifsud, n.d.). Overall Relative Efficiency pada Persamaan 1 menggunakan rasio waktu yang dibutuhkan oleh pengguna saat berhasil menyelesaikan tugas dengan total waktu yang dibutuhkan oleh semua pengguna (Anton Sergeev, n.d.; ISO - ISO/IEC 25022:2016 Systems and Software Engineering - Systems and Software Quality Requirements and Evaluation (SQuaRE) - Measurement of Quality in Use, n.d.; Justin Mifsud, n.d.). Overall relative efficiency menggunakan indikator waktu untuk menyelesaikan task dan completion task dengan memberi nilai 1 pada task success dan nilai 0 pada task yang gagal. Metriks time on task adalah cara untuk memastikan efisiensi suatu produk (Luchita, 2019).

Memorability diukur menggunakan metrik duration metrics. Pengujian akan dilakukan dengan mengukur waktu penyelesaian task yang akan diulang sebanyak 3 kali. Semakin menurun waktu yang dibutuhkan peserta dalam 
menyelesaikan task, semakin baik nilai memorability aplikasi tersebut. Hal ini mengacu pada seberapa cepat pengguna dapat kembali mengingat dalam menggunakan desain setelah beberapa waktu dengan mengacu pada pertanyaan "Bagaimana kemampuan pengguna mempertahankan pengetahuannya setelah jangka waktu tertentu?" (Nielsen, 2012a). Jika terjadi penurunan waktu pengerjaan atau waktu pengerjaan sama maka dapat dikatakan bahwa aplikasi tersebut memiliki nilai memorability yang baik, Begitu pula sebaliknya jika terjadi kenaikan waktu pengerjaan maka nilai memorability dari aplikasi tersebut buruk (Louis, 2003).

Errors dapat diukur dengan menggunakan indikator jumlah error rate pada saat pengujian aplikasi. Semakin rendah tingkat error rate yang terdeteksi pada sistem maka semakin baik pula sistem yang dibuat. Sebaliknya, semakin tinggi tingkat error rate yang terdeteksi pada sistem maka semakin buruk sistem yang dibuat (Nielsen, 2012a). penghitungan nilai error rate pada Persamaan 2 digunakan dalam penelitian ini untuk mengukur tingkat error (Helmenstine, 2020).

Tabel 1. Parameter dan Metriks Pengujian (Hartson \& Pyla, 2018; Jakob Nielsen, 2001; Luchita, 2019; Nielsen, 2001)

\begin{tabular}{|c|c|c|}
\hline Parameter & Metriks & Keterangan \\
\hline $\begin{array}{c}\text { Efektifitas, } \\
\text { Efisiensi }\end{array}$ & Completion & $\begin{array}{l}\text { mengukur keberhasilan partisipan dalam menyelesaikan task. } \\
\text { Setiap task dapat dianggap berhasil secara langsung (direct } \\
\text { success, nilai } 1 \text { ) atau gagal (fail, nilai 0), dan ada dalam } \\
\text { beberapa kasus, task tersebut selesai, tetapi tidak lancar (indirect } \\
\text { succes, nilai } 0.5 \text { ). }\end{array}$ \\
\hline Efektifitas & Error & $\begin{array}{l}\text { kesalahan yang dilakukan pengguna dalam menjalankan sebuah } \\
\text { aplikasi. Diukur dengan melihat misclick rate, jumlah kesalahan } \\
\text { klik atau tap yang dilakukan pengguna saat menjalankan } \\
\text { purwarupa }\end{array}$ \\
\hline $\begin{array}{l}\text { Efisiensi, } \\
\text { Memorability }\end{array}$ & $\begin{array}{l}\text { Time on } \\
\text { screen }\end{array}$ & $\begin{array}{l}\text { mengukur seberapa lama pengguna menghabiskan waktu } \\
\text { untuk menyelesaikan suatu task. }\end{array}$ \\
\hline Satisfaction & SUS & $\begin{array}{l}\text { Sepuluh pernyataan kuesioner masing-masing dengan lima } \\
\text { pilihan jawaban untuk mengevaluasi usability secara kuantitatif }\end{array}$ \\
\hline
\end{tabular}

$P=\frac{\sum_{j=1}^{R} \sum_{i=1}^{N} n_{i j} t_{i j}}{\sum_{j=1}^{R} \sum_{i=1}^{N} t_{i j}} * 100 \%$

Ket:

$P=$ Tingkat Efisiensi

$N=$ total task yang digunakan dalam penelitian

$R=$ Jumlah evaluator

$n_{i j}=$ hasil dari task scenario $i$ dari evaluator $j$; (1 direct success, 0 fail, 0.5 Indirect success)

$t_{i j}=$ Waktu yang digunakan evaluator $j$ untuk menyelesaikan task $i$. Jika task tidak dapat diselesaikan, maka waktu akan diukur saat terakhir evaluator menyerah untuk menyelesaikan task.

$E=\frac{|B-S|}{B} * 100 \%$

Ket:

$E=$ Error Rate

$B=$ Nilai Teoritis

$S=$ Nilai Percobaan

Perhitungan yang dilakukan untuk menghitung nilai satisfaction adalah dengan menggunakan System Usability Scale (SUS) (Drew et al., 2018; Jeng, 2005; Kaya et al., 2019). Kuesioner ini berfungsi untuk mengukur kesan mereka terhadap keseluruhan kemudahan penggunaan sistem yang diuji (Thomas, n.d.). Evaluator akan diberikan 10 pernyataan. Setiap pernyataan memiliki rating 1 sampai dengan 5 . Nilai 1 menunjukkan evaluator sangat tidak setuju dan nilai 5 menunjukkan evaluator sangat setuju dengan pernyataan tersebut. Untuk pernyataan dengan urutan ganjil nilai akan dikurangi 1 . Pernyataan dengan urutan genap nilai 5 dikurangi dengan nilai pernyataan tersebut. Setelah itu, hasil pernyataan ganjil dan hasil pernyataan genap dijumlahkan. Terakhir, hasil penjumlahan dikalikan dengan 2,5. Standar dari SUS ini adalah 68 (Thomas, n.d.; Tullis \& Albert, 2013). Jika nilai SUS penelitian ini dibawah 68 maka terdapat masalah yang serius di purwarupa aplikasi Mata Kampus. Nilai SUS 68 produk tersebut bagus, tetapi harus ada perbaikan yang dilakukan. Nilai SUS 80 atau diatasnya berarti user menyukai produk dan akan merekomendasikan produk ke temannya. Pada penelitian ini, kuesioner SUS yang digunakan adalah versi bahasa Indonesia (Sharfina \& Santoso, 2017).

Evaluator pada penelitian harus merupakan pengguna secara realistis dari produk atau jasa yang akan diteliti. dalam 
beberapa kasus pengujian, peserta mungkin hanya memiliki latar belakang yang mirip dengan grup pengguna yang sebenarnya atau mungkin memiliki kebutuhan yang sama, bahkan jika dia belum menjadi pengguna produk atau jasa yang ingin diteliti(Sova \& Nielsen, n.d.). Untuk memilih evaluator sebelumnya dilakukan profiling pengguna menggunakan user persona. Persona adalah sebuah representasi pengguna dalam bentuk individu imajiner yang memuat rumusan singkat mengenai karakteristik, pengalaman, tujuan, tasks, pain points, dan kondisi lingkungan pengguna yang sebenarnya (Muider \& Yaar, 2006; Tamara Adlin \& John Pruitt, 2010). Setiap persona menggambarkan sekelompok orang di dunia nyata. Tujuan dari user persona adalah membuat sebuah penggambaran yang realistis dan bisa diandalkan mengenai segmen pengguna untuk dijadikan referensi (Persona / Usability Body of Knowledge, n.d.). Evaluator dalam penelitian ini berjmlah $3-5$ peserta untuk tiap user persona (Nielsen, 2000, 2012b; Nielsen et al., 2006)

Cara paling efektif untuk memahami dan menilai usability dari sebuah aplikasi adalah dengan melihat orang - orang menggunakan aplikasi tersebut. Untuk mengamati peserta, evaluator yang pada penelitian ini mewakili pengguna diberikan tugas yang akan disebutkan sebagai task. Task ini akan dibuatkan dalam skenario singkat yang menunjukan tindakan dan sedikit penjelasan yang harus dilakukan oleh peserta. Task skenario akan dibuat berdasarkan tujuan yang ingin dicapai oleh pengguna. Masing-masing memiliki tujuan yang berbeda seperti ditunjukkan pada Tabel 2. Task scenario dibuat dengan menentukan tugas pengguna yang paling penting dan menentukan fitur atau sistem yang ingin diteliti (Farrell, 2017). Selain itu, dalam pembuatan task scenario harus realistis, actionable, dan langkah tidak boleh terlalu detail (McCloskey, 2014).

Sebelum dilakukan pengujian, penelitian ini mengumpulkan data nilai metriks standard yang akan digunakan untuk perbandingan. Standar metrik adalah sebuah standar pengukuran yang sebelumnya telah ditetapkan oleh tim pengembang aplikasi Mataku. Standar ini akan dijadikan bahan perbandingan untuk pengolahan data hasil pengujian. Standar ini didapatkan dari hasil pelaksanaan pengujian yang dilakukan oleh tim pengembang aplikasi Mataku dengan task yang sama. Standar yang ditetapkan yaitu completion task, duration, errors, dan number of steps.

Pengujian dilakukan dalam empat tahap; persiapan, pengenalan, pengujian, dan evaluasi. Pada tahap persiapan dilakukan persiapan terhadap ruang uji dan memastikan bahwa peralatan untuk proses pengumpulan data siap digunakan sehingga tidak mengganggu proses pengumpulan data. Untuk meminimalkan ketidaknyamanan evaluator, persiapan ini harus diselesaikan sebelum kedatangan evaluator tersebut (Nielsen, 1994). Pada tahap pengenalan, evaluator diberikan penjelasan singkat mengenai tujuan test dan penjelasan mengenai prosedur pelaksanaan pengujian, penjelasan singkat tentang aplikasi Mataku yang menjadi objek evaluasi, serta hal-hal yang mungkin dialami atau dampak dari proses pengujian ini terhadap evaluator. Tahap pengujian dijalankan berdasarkan task scenario yang telah ditetapkan sebelumnya. Waktu yang digunakan selama pengujian akan dicatat secara manual oleh peneliti. Pada tahapan evaluasi, evaluator diminta mengisi kuesioner SUS yang disediakan pada Google Form dan wawancara singkat untuk menggali komentar tentang apapun permasalahan yang dihadapinya ketika menjalani tes dan saran yang mungkin mereka miliki untuk perbaikan sistem.

Pada tahap analisis, data dari hasil pengujian digunakan untuk menghitung metrik pengujian yang ada pada Tabel 1. Hasil perhitungan ini bersama dengan hasil perhitungan kuesioner SUS digunakan untuk melihat permasalahan yang dihadapi oleh evaluator.

Berdasarkan permasalahan yang didapatkan dari tahapan analisis, didapatkan fitur-fitur yang nilai usabilitasnya rendah. Artinya, ada masalah pada desain dan fitur memerlukan perbaikan. Rekomendasi desain perbaikan dibuat dalam bentuk prototipe high fidelity menggunakan aplikasi Figma. Rekomendasi perbaikian ini belum tentu meningkatkan nilai usability dari prototipe aplikasi Mataku. Mungkin saja justru memperburuk nilai usabilitas. Oleh karena itu, dibutuhkanlah evaluasi kembali terhadap rekomendasi perbaikan yang telah dibuat. Evaluasi dilakukan dengan melakukan pengulangan pengujian usability terhadap rekomendasi solusi yang ditawarkan. Untuk memvalidasi solusi yang ditawarkan, penelitian ini menggunakan alat, partisipan, dan task skenario yang sama seperti pada saat pengujian pertama.

\section{Hasil dan Pembahasan}

Tiga persona yang digunakan dalam penelitian ini adalah Barbara, Danang dan Dinda. Barbara berusia antara 20-40 tahun, tidak memiliki gangguan penglihatan, membutuhkan surat keterangan bebas buta warna untuk mendaftar pekerjaan. Danang, berusia antara 20-40 tahun, memiliki gangguan penglihatan miopi, berupaya agar secara teratur memeriksakan kesehatan matanya setiap tahun 
meskipun memiliki jadwal kerja yang padat. Dinda, usia > 40 tahun, memiliki gangguan penglihatan dan menggunakan kacamata yang langsung dibeli dari optik terdekat. Dinda tidak pernah memeriksakan mata secara teratur dan belakangan merasa perlu untuk memeriksakan matanya karena teman arisan yang tiba-tiba kehilangan penglihatan karena Glukoma. Dari persona ini diperoleh tujuan penggunan menggunakan aplikasi Mataku seperti pada Tabel 2.

Tabel 2. Tujuan Pengguna (Adhytia Ihza Mahendra, 2021)

\begin{tabular}{|c|c|}
\hline Persona & Tujuan \\
\hline Barbara & $\begin{array}{l}\text { (1) Melakukan pemeriksaan } \\
\text { mata insidentil }\end{array}$ \\
\hline Danang & $\begin{array}{l}\text { (2) Melakukan pemeriksaan } \\
\text { mata rutin dengan mudah } \\
\text { (tanpa proses yang rumit) } \\
\text { dan cepat (tidak perlu } \\
\text { mengantri) }\end{array}$ \\
\hline Dinda & $\begin{array}{l}\text { (3) Melakukan konsultasi } \\
\text { dengan dokter mata secara } \\
\text { rutin }\end{array}$ \\
\hline
\end{tabular}

Penelitian ini melibatkan 9 evaluator yang telah disesuaikan dengan user persona; 3 orang dari umur 20 hingga 40 tahun, 3 peserta berumur 20 - 40 dengan gangguan penglihatan, dan 3 peserta dengan umur diatas 40 tahun. Seluruh kelompok evaluator dipilih dengan jenis kelamin dan latar belakang pekerjaan acak.

Masing-masing evaluator diminta menjalankan skenario yang ditentukan pada Tabel 3.

Tabel 3. Daftar Task Scenario (Adhytia Ihza Mahendra, 2021)

\begin{tabular}{cl}
\hline $\begin{array}{c}\text { Task } \\
\text { No }\end{array}$ & \multicolumn{1}{c}{ Task Scenario } \\
\hline 1 & Lakukan pemeriksaan katarak \\
2 & $\begin{array}{l}\text { Lakukan pemeriksaan buta warna } \\
\text { lalu kembali ke menu utama }\end{array}$ \\
3 & $\begin{array}{l}\text { Lakukan pemeriksaan rabun jauh } \\
\text { lalu kembali ke menu utama } \\
\text { Lakukan konsultasi dengan Dr. } \\
\text { James }\end{array}$ \\
\hline
\end{tabular}

Tabel 4. Pengukuran Learnability dan Memorability (Adhytia Ihza Mahendra, 2021)

\begin{tabular}{|c|c|c|c|c|c|c|c|c|c|c|c|}
\hline \multirow{2}{*}{ Task } & \multirow{2}{*}{ Partisipan } & \multicolumn{3}{|c|}{ Completion Task } & \multicolumn{3}{|c|}{ Errors } & \multicolumn{3}{|c|}{ Duration } & \multirow{2}{*}{ Tingkat Learnability } \\
\hline & & Test1 & Test2 & Test3 & Test1 & Test2 & Test3 & Test1 & Test2 & Test3 & \\
\hline \multirow{9}{*}{1} & P1 & 1 & 1 & 1 & 0 & 0 & 0 & 28 & 14 & 10 & \multirow{9}{*}{$83 \%$} \\
\hline & P2 & 0,5 & 1 & 1 & 1 & 1 & 1 & 22 & 12 & 10 & \\
\hline & P3 & 1 & 1 & 1 & 0 & 0 & 0 & 12 & 6 & 4 & \\
\hline & P4 & 1 & 1 & 1 & 0 & 0 & 0 & 6 & 5 & 5 & \\
\hline & P5 & 1 & 1 & 1 & 0 & 0 & 0 & 7 & 7 & 6 & \\
\hline & P6 & 1 & 1 & 1 & 0 & 0 & 0 & 11 & 6 & 5 & \\
\hline & P7 & 1 & 1 & 1 & 0 & 0 & 0 & 8 & 6 & 5 & \\
\hline & P8 & 0,5 & 0,5 & 0,5 & 4 & 4 & 2 & 26 & 15 & 15 & \\
\hline & P9 & 0,5 & 0,5 & 0,5 & 2 & 4 & 2 & 14 & 16 & 11 & \\
\hline \multirow{9}{*}{2} & P1 & 1 & 1 & 1 & 0 & 0 & 0 & 24 & 15 & 11 & \multirow{9}{*}{$100 \%$} \\
\hline & P2 & 1 & 1 & 1 & 0 & 0 & 0 & 25 & 13 & 11 & \\
\hline & P3 & 1 & 1 & 1 & 0 & 0 & 0 & 23 & 10 & 10 & \\
\hline & P4 & 1 & 1 & 1 & 0 & 0 & 0 & 13 & 8 & 8 & \\
\hline & P5 & 1 & 1 & 1 & 0 & 0 & 0 & 12 & 11 & 9 & \\
\hline & P6 & 1 & 1 & 1 & 0 & 0 & 0 & 10 & 10 & 7 & \\
\hline & P7 & 1 & 1 & 1 & 0 & 0 & 0 & 15 & 10 & 10 & \\
\hline & P8 & 1 & 1 & 1 & 0 & 0 & 0 & 24 & 14 & 13 & \\
\hline & P9 & 1 & 1 & 1 & 0 & 0 & 0 & 17 & 14 & 13 & \\
\hline \multirow{9}{*}{3} & P1 & 1 & 1 & 1 & 0 & 0 & 0 & 19 & 10 & 9 & \multirow{9}{*}{$100 \%$} \\
\hline & P2 & 1 & 1 & 1 & 0 & 0 & 0 & 16 & 12 & 10 & \\
\hline & P3 & 1 & 1 & 1 & 0 & 0 & 0 & 15 & 8 & 8 & \\
\hline & P4 & 1 & 1 & 1 & 0 & 0 & 0 & 10 & 10 & 8 & \\
\hline & P5 & 1 & 1 & 1 & 0 & 0 & 0 & 11 & 11 & 9 & \\
\hline & P6 & 1 & 1 & 1 & 0 & 0 & 0 & 10 & 10 & 7 & \\
\hline & P7 & 1 & 1 & 1 & 0 & 0 & 0 & 14 & 10 & 7 & \\
\hline & P8 & 1 & 1 & 1 & 0 & 0 & 0 & 20 & 15 & 13 & \\
\hline & P9 & 1 & 1 & 1 & 0 & 0 & 0 & 14 & 12 & 11 & \\
\hline
\end{tabular}




\begin{tabular}{|c|c|c|c|c|c|c|c|c|c|c|c|}
\hline \multirow{2}{*}{ Task } & \multirow{2}{*}{ Partisipan } & \multicolumn{3}{|c|}{ Completion Task } & \multicolumn{3}{|c|}{ Errors } & \multicolumn{3}{|c|}{ Duration } & \multirow[b]{2}{*}{ Tingkat Learnability } \\
\hline & & Test1 & Test2 & Test3 & Test1 & Test2 & Test3 & Test1 & Test2 & Test3 & \\
\hline \multirow{9}{*}{4} & P1 & 1 & 1 & 1 & 0 & 0 & 0 & 13 & 7 & 5 & \multirow{9}{*}{$100 \%$} \\
\hline & P2 & 1 & 1 & 1 & 0 & 0 & 0 & 12 & 7 & 6 & \\
\hline & P3 & 1 & 1 & 1 & 0 & 0 & 0 & 16 & 6 & 5 & \\
\hline & P4 & 1 & 1 & 1 & 0 & 0 & 0 & 6 & 5 & 4 & \\
\hline & P5 & 1 & 1 & 1 & 0 & 0 & 0 & 8 & 7 & 6 & \\
\hline & P6 & 1 & 1 & 1 & 0 & 0 & 0 & 5 & 5 & 4 & \\
\hline & P7 & 1 & 1 & 1 & 0 & 0 & 0 & 7 & 6 & 6 & \\
\hline & P8 & 1 & 1 & 1 & 0 & 0 & 0 & 15 & 10 & 10 & \\
\hline & P9 & 1 & 1 & 1 & 0 & 0 & 0 & 8 & 7 & 6 & \\
\hline
\end{tabular}

Tabel 5. Pengukuran Efisiensi dan Error (Adhytia Ihza Mahendra, 2021)

\begin{tabular}{|c|c|c|c|c|c|c|c|c|}
\hline Task & Partisipan & $\begin{array}{c}\text { Completion } \\
\text { Task }\end{array}$ & Durasi & $\begin{array}{c}\text { Waktu } \\
\text { Rata-rata }\end{array}$ & Error & $\begin{array}{l}\text { Number } \\
\text { of Steps }\end{array}$ & $\mathrm{P}$ & $\begin{array}{l}\text { Error } \\
\text { Rate }\end{array}$ \\
\hline \multirow{9}{*}{1} & P1 & 1 & 28 & \multirow{9}{*}{14,8} & 0 & 4 & \multirow{9}{*}{$76,9 \%$} & \multirow{9}{*}{$19,4 \%$} \\
\hline & P2 & 0,5 & 22 & & 1 & 5 & & \\
\hline & P3 & 1 & 12 & & 0 & 4 & & \\
\hline & P4 & 1 & 6 & & 0 & 4 & & \\
\hline & P5 & 1 & 7 & & 0 & 4 & & \\
\hline & P6 & 1 & 11 & & 0 & 4 & & \\
\hline & P7 & 1 & 8 & & 0 & 4 & & \\
\hline & P8 & 0,5 & 26 & & 4 & 8 & & \\
\hline & P9 & 0,5 & 14 & & 2 & 6 & & \\
\hline \multirow{9}{*}{2} & P1 & 1 & 24 & \multirow{9}{*}{18,11} & 0 & 9 & \multirow{9}{*}{$100 \%$} & \multirow{9}{*}{$0 \%$} \\
\hline & P2 & 1 & 25 & & 0 & 9 & & \\
\hline & P3 & 1 & 23 & & 0 & 9 & & \\
\hline & P4 & 1 & 13 & & 0 & 9 & & \\
\hline & P5 & 1 & 12 & & 0 & 9 & & \\
\hline & P6 & 1 & 10 & & 0 & 9 & & \\
\hline & P7 & 1 & 15 & & 0 & 9 & & \\
\hline & P8 & 1 & 24 & & 0 & 9 & & \\
\hline & P9 & 1 & 17 & & 0 & 9 & & \\
\hline \multirow{9}{*}{3} & P1 & 1 & 19 & \multirow{9}{*}{14,3} & 0 & 9 & \multirow{9}{*}{$100 \%$} & \multirow{9}{*}{$0 \%$} \\
\hline & P2 & 1 & 16 & & 0 & 9 & & \\
\hline & P3 & 1 & 15 & & 0 & 9 & & \\
\hline & P4 & 1 & 10 & & 0 & 9 & & \\
\hline & P5 & 1 & 11 & & 0 & 9 & & \\
\hline & P6 & 1 & 10 & & 0 & 9 & & \\
\hline & P7 & 1 & 14 & & 0 & 9 & & \\
\hline & P8 & 1 & 20 & & 0 & 9 & & \\
\hline & P9 & 1 & 14 & & 0 & 9 & & \\
\hline \multirow{9}{*}{4} & P1 & 1 & 13 & \multirow{9}{*}{10} & 0 & 5 & \multirow{9}{*}{$100 \%$} & \multirow{9}{*}{$0 \%$} \\
\hline & P2 & 1 & 12 & & 0 & 5 & & \\
\hline & P3 & 1 & 16 & & 0 & 5 & & \\
\hline & P4 & 1 & 6 & & 0 & 5 & & \\
\hline & P5 & 1 & 8 & & 0 & 5 & & \\
\hline & P6 & 1 & 5 & & 0 & 5 & & \\
\hline & P7 & 1 & 7 & & 0 & 5 & & \\
\hline & P8 & 1 & 15 & & 0 & 5 & & \\
\hline & P9 & 1 & 8 & & 0 & 5 & & \\
\hline
\end{tabular}


Tabel 6. Pengukuran Kepuasan (Adhytia Ihza Mahendra, 2021)

\begin{tabular}{ccccc}
\hline Partisipan & $\begin{array}{c}\text { Total Pernyataan } \\
\text { Ganjil }\end{array}$ & $\begin{array}{c}\text { Total Pernyataan } \\
\text { Genap }\end{array}$ & $\begin{array}{c}\text { Total Nilai } \\
\text { Kepuasan }\end{array}$ & $\begin{array}{c}\text { Rata-rata } \\
\text { kepuasan }\end{array}$ \\
\hline P1 & 15 & 12 & 67,5 & \\
P2 & 13 & 16 & 72,5 & \\
P3 & 20 & 18 & 95 & \\
P4 & 19 & 20 & 97,5 & \\
P5 & 16 & 16 & 80 & 85,27 \\
P6 & 18 & 20 & 95 & \\
P7 & 19 & 18 & 92,5 & \\
P8 & 18 & 16 & 85 & \\
P9 & 18 & 15 & 82,5 & \\
\hline
\end{tabular}

Dari keempat task yang dilakukan oleh evaluator dapat dilihat bahwa task pertama memiliki nilai learnability, efisiensi, memorability yang paling rendah dan nilai error rate paling tinggi. Berdasarkan hasil kuesioner evaluasi permasalahan yang terjadi adalah evaluator mengira gambar belum dimasukkan secara otomatis dan mengira tombol ambil gambar / unggah gambar untuk mengubah gambar adalah tombol untuk memasukkan gambar saat pertama kali. Karena itu akan dilakukan desain perbaikan terhadap fitur pemeriksaan katarak. Seperti ditunjukkan pada Gambar 1.

\section{Sebelum Perbaikan}

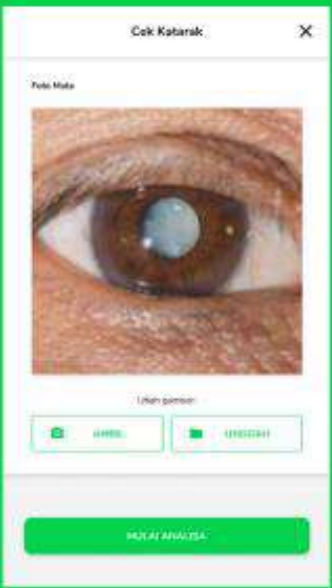

\section{Sesudah Perbaikan}

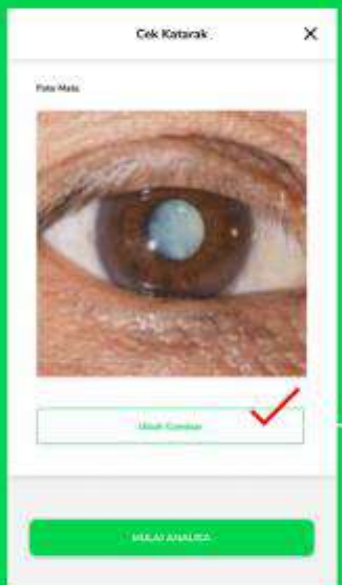

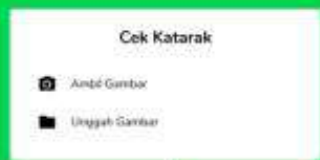

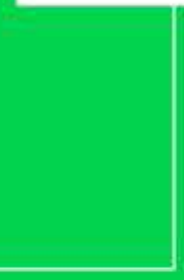

Gambar 2. Perbaikan Desain untuk Fitur Pemeriksaan Katarak

Untuk mengetahui apakah rekomendasi solusi yang ditawarkan oleh peneliti dapat meningkatkan nilai usability dari prototipe aplikasi Mataku diperlukan peninjauan kembali terhadap solusi yang ditawarkan atau dapat disebut validasi rekomendasi. Validasi rekomendasi ini akan dilakukan sebanyak 1 kali dengan task yang sama sesuai dengan perbaikan. Penelitian ini menggunakan orang floater (peserta cadangan). Hal ini dilakukan karena salah satu peserta tidak dapat menghadiri jadwal. Floater dipilih dengan dasar kriteria yang sama dengan user persona yang sudah ditentukan dan peserta yang digantikan (Pernice, 2020).Hal ini dilakukan atas dasar jadwal pengujian yang singkat dan tidak memungkinkan bagi peserta tersebut untuk ikut dalam proses validasi ini. Validasi ini dilakukan dengan membandingkan nilai usability dari hasil pengujian usability sebelumnya seperti yang ditunjukkan pada Tabel 7 .

Tabel 7. Tujuan Pengguna (Adhytia Ihza Mahendra, 2021)

\begin{tabular}{ccc}
\hline Metriks & Hasil Awal & Hasil Perbaikan \\
\hline Learnability & $80 \%$ & $100 \%$ \\
Efisiensi & $85,3 \%$ & $100 \%$ \\
memorability & Buruk & Buruk \\
Errors & $5 \%$ & $0 \%$ \\
satisfaction & 82,5 & - \\
\hline
\end{tabular}


Berdasarkan hasil pengujian terhadap desain perbaikan pada Tabel 7, didapatkan kenaikan nilai usability untuk komponen learnability, efisiensi, dan errors. Namun, waktu yang dihabiskan evaluator untuk melakukan task tersebut mengalami kenaikan baik pada ketiga kali pengujian sehingga nilai memorability menurun. Penurunan nilai memorability ini kemungkinan dipengaruhi oleh penamaan fungsi yang kurang mewakili kegunaannya dan tulisan pada aplikasi yang kecil, serta ketidak konsistenan disain. Proses perbaikan dan evalusi seharusnya dilakukan secara interatif hingga mendapatkan hasil yang cukup baik, namun pada penelitian ini iterasi dibatasi hanya dua kali.

\section{Kesimpulan}

Penelitian yang bertujuan mengukur dan meningkatkan kualitas perangkat lunak mobile dari sisi usability ini menggunakan pendekatan usability testing dan kuesioner System Usability Scale. Tingkat usabilitas diukur dengan parameter learnability, efisiensi, memorability, error, dan satisfaction. Menggunakan pendekatan ini, berhasil ditemukan masalah pada desain salah satu fitur yang ditandai dengan rendahnya nilai memorability dan efisiensi serta tingginya nilai error. Perbaikan desain terhadap fitur yang bermasalah berhasil memperbaiki nilai error dan efisiensi namun belum berhasil meningkatkan nilai memorability. Beberapa hal yang dapat dilakukan pada iterasi berikutnya untuk meningkatkan memorability adalah membuat desain tampilan dan alur yang konsisten antara satu fitur dengan fitur lainnya, memperbaiki kata-kata yang digunakan untuk menjelaskan suatu fungsi serta memperhatikan ukuran setiap komponen desain. Selain melanjutkan iterasi, penelitian selanjutnya dapat mencoba menambahkan metriks pengujian agar hasil yang didapatkan lebih objektif.

\section{Referensi}

Adhytia Ihza Mahendra. (2021). Analisis Usability User Interface Menggunakan Metode Usability Testing Pada Prototype Aplikasi Mataku. https://library. universitaspertamina.ac.id//xmlui/handle/1 23456789/3529

Anton Sergeev. (n.d.). UI Designer - ISO-9241 Efficiency metrics - Theory of usability. Retrieved June 20, 2021, from http://uidesigner.net/usability/efficiency.htm

Belson, H., \& Ho, J. (2012). A Fresh Graduate's Guide to Software Development Tools and Technologies Chapter Usability CHAPTER AUTHORS. In A Fresh Graduate's Guide to Software Development Tools and Technologies. School of Computing, National University of Singapore.

Drew, M. R., Falcone, B., \& Baccus, W. L. (2018). What Does the System Usability Scale (SUS) Measure? Validation Using Think Aloud Verbalization and Behavioral Metrics. In Design, User Experience, and Usability: Theory and Practice. Springer, Cham. https://doi.org/10.1007/978-3-31991797-9

Farrell, S. (2017, September 17). From Research Goals to Usability-Testing Scenarios: A 7-Step Method. https://www. nngroup.com/articles/ux-research-goalsto-scenarios/

Hartson, R., \& Pyla, P. (2018). The UX book: Agile UX design for a quality user experience. In The UX Book: Agile UX Design for a Quality User Experience. Elsevier. https://doi.org/10.1016/C2013-019285-9

Helmenstine, A. M. (2020, October 2). How to Calculate Percent Error. https://www.thoughtco.com/how-tocalculate-percent-error-609584

ISO - ISO/IEC 25022:2016 - Systems and software engineering - Systems and software quality requirements and evaluation (SQuaRE) - Measurement of quality in use. (n.d.). Retrieved June 20, 2021, from https://www.iso.org/standard/35746.html

Jakob Nielsen. (2001, February 17). Success Rate: The Simplest Usability Metric. https://www.nngroup.com/articles/success -rate-the-simplest-usability-metric/

Jeng, J. (2005). Usability Assessment of Academic Digital Libraries: Effectiveness, Effi ciency, Satisfaction, and Learnability.

Justin Mifsud. (n.d.). Usability Metrics - A Guide To Quantify The Usability Of Any System Usability Geek. Retrieved June 20, 2021, from https://usabilitygeek.com/usabilitymetrics-a-guide-to-quantify-systemusability/

Kaya, A., Ozturk, R., \& Altin Gumussoy, C. (2019). Usability Measurement of Mobile Applications with System Usability Scale (SUS). 389-400. https://doi.org/10. 1007/978-3-030-03317-0_32

Kementerian Kesehatan Republik Indonesia. (n.d.). Retrieved June 30, 2021, from https://www.kemkes.go.id/article/view/160 11100003/katarak-sebabkan-50kebutaan.html

Louis, T. (2003, June 19). Usability 101: Memorability - Tristan Louis (TNL.net). http://www.tnl.net/blog/2003/06/19/usabilit $y$-101-memorability/ 
Luchita, E. (2019). Measuring user experience with usability metrics. https://maze. $\mathrm{co} / \mathrm{blog} /$ measure-usability-metrics/

McCloskey, M. (2014, January 12). Task Scenarios for Usability Testing. https://www.nngroup.com/articles/taskscenarios-usability-testing/

Moran, K. (2019, December 1). Usability Testing 101.

https://www.nngroup.com/articles/usability -testing-101/

Muider, S., \& Yaar, Z. (2006). The User Is Always Right: A Practical Guide to Creating and Using Personas for the Web [Book]. New Riders. https://www.oreilly.com/ library/view/the-user-is/0321449924/

Nielsen, J. (1994). Usability Engineering. Morgan Kaufman Publisher.

Nielsen, J. (2000, March 18). Why You Only Need to Test with 5 Users. https://www.nngroup.com/articles/whyyou-only-need-to-test-with-5-users/

Nielsen, J. (2001). Usability Metrics. https://www.nngroup.com/articles/usability -metrics/

Nielsen, J. (2012a, January 3). Usability 101: Introduction to Usability. https://www.nngroup.com/articles/usability -101-introduction-to-usability/

Nielsen, J. (2012b, June 3). How Many Test Users in a Usability Study? https://www.nngroup.com/articles/howmany-test-users/

Nielsen, J., Lewis, J., \& Turner, C. (2006). Determining Usability Test Sample Size. International Encyclopedia of Ergonomics and Human Factors, Second Edition - 3 Volume Set, April. https://doi.org/10.1201/9780849375477.ch 597

Pernice, K. (2020, October 4). Recruiting Backup Participants (aka "Floaters") in User Research. https://www.nngroup. com/articles/recruit-backup-users-inresearch/

Persona / Usability Body of Knowledge. (n.d.). Retrieved June 30, 2021, from http://www.usabilitybok.org/persona

Rubin, J., \& Chisnell, D. (2018). Handbook of
Usability Testing / Guide books (2nd ed.). John Wiley \& Sons, Inc. https://dl.acm.org/doi/10.5555/561768

Sahlan. (2013, February 9). Perlu Penanganan Jumlah Penderita Penyakit Mata Cukup Tinggi / Neraca.co.id. https://www.neraca. co.id/article/24657/perlu-penangananjumlah-penderita-penyakit-mata-cukuptinggi

Sharfina, Z., \& Santoso, H. B. (2017). An Indonesian adaptation of the System Usability Scale (SUS). 2016 International Conference on Advanced Computer Science and Information Systems, ICACSIS 2016, 145-148. https://doi.org/10.1109/ICACSIS.2016.787 2776

Sova, D. H., \& Nielsen, J. (n.d.). 234 Tips and Tricks for Recruiting the Right Users as Participants in Usability Studies. Retrieved June 30, 2021, from www.nngroup.com/reports/how-to-recruitparticipants-usability-studies

Tamara Adlin, \& John Pruitt. (2010). The Essential Persona Lifecycle: Your Guide to Building and Using Personas - 1st Edition (1st ed.). Morgan Kaufmann. https://www.elsevier.com/books/theessential-persona-lifecycle-your-guide-tobuilding-and-using-personas/adlin/978-012-381418-0

Thomas, N. (n.d.). How To Use The System Usability Scale (SUS) To Evaluate The Usability Of Your Website - Usability Geek. Retrieved June 20, 2021, from https://usabilitygeek.com/how-to-use-thesystem-usability-scale-sus-to-evaluatethe-usability-of-your-website/

Tullis, T., \& Albert, B. (2013). Measuring the User Experience: Collecting, Analyzing, and Presenting Usability Metrics: Second Edition. In Measuring the User Experience: Collecting, Analyzing, and Presenting Usability Metrics: Second Edition. Elsevier Inc. $\quad$ https://doi.org/10.1016/C2011-000016-9 